\title{
Evaluation of The Performance of Covid-19 Task Force on The Accuracy of Drug Administration According to Complaints, Responsiveness Forcomplaints, Compliance of Patients Self-Isolation Taking Drugs, The Need for Task Force and The Duration of Recovery in RT 007 RW 25 Bekasi City 16 June-31 July 2021
}

\author{
AnisaFajarini $^{1}$, Sugiyanto $^{2}$ \\ \{Anisa.fajarini@yahoo.com ${ }^{1}$, Sugiyantosaleh17@gmail.com²\} \\ Universitas Borobudur, Jakarta, Indonesia ${ }^{1,2}$
}

\begin{abstract}
This study aims to evaluate the performance of the Covid 19 Task Force on the accuracy of drug administration according to complaints, duration of the task force response to complaints, patient compliance with therapy and duration of recovery in RT 25 RW 25 Bekasi City. This research is a type of exploratory descriptive research so it cannot test the hypothesis. The data used in this research is primary data. The sampling technique was carried out through accidental sampling with snowball sampling as many as 32 responden self isolation patients from 53 self isolation patients in RT 7 RW 25 Bekasi city as a sample. The method of collecting data is using a self-administrated survey, by providing a questionnaire. The method of analysis in this research is descriptive analysis method.
\end{abstract}

Keywords: Covid 19 Task Force on the accuracy of drug administration according to complaints; duration of the task force response to complaints; patient compliance with therapy and duration of recovery

\section{Introduction}

On December 31, 2019, China Country Offce reported an unknown case of pneumonia in Wuhan is the city of Hubei Province in China. China identified the unknown pneumonia as a new type of coronavirus on January 7, 2020. NCP became a global endemic and a health hazard in several countries outside of the PRC in early 2020. Cases of pneumonia clusters with unknown etiologies in Wuhan city have become a worldwide health hazard, according to the World Health Organization (WHO). The epidemic will continue to spread until the cause of this pneumonia cluster is identified as new coronavirus. The pandemic grew until new cases and deaths were reported outside of China. COVID-19 was designated a Public Health Emergency of International Concern by the World Health on January 30, 2020. (PHEIC) The 
World Health Assembly (WHO) officially recognized this new coronavirus disease on February 12, 2020 in humans as Coronavirus Disease (COVID-19). SARS-COV2, which causes COVID-19, is a part of the same large family of coronaviruses that caused SARS in 2003, although it is a different type of virus. Although the symptoms are similar to SARS, COVID-19 has a greater fatality rate (9.6\%) than SARS (now less than 5\%), although the fact that the number of cases is significantly higher. COVID-19 has also spread to more nations and at a faster rate than SARS. [1]

On March 9, 2020, the World Health Organization (WHO) proclaimed the coronavirus (COVID-19) a pandemic. That is to say, the corona virus has spread globally. The term pandemic may seem scary, but it refers to the disease's widespread spread rather than its severity. Remember that coronavirus usually produces mild to moderate symptoms like fever and cough, and that most patients heal within a few weeks. However, the coronavirus can cause major health problems in some persons at high risk (the elderly and people with chronic health conditions like heart disease, high blood pressure, or diabetes). The majority of the victims belonged to the vulnerable demographic. That is why it is critical that we all learn how to lower risk, be informed, and know what to do if we experience symptoms. We will be able to safeguard ourselves and others in this manner.[2]

In early 2020, the world is faced with the disaster of the 2019 Coronavirus Disease pandemic outbreak, known as Covid-19, where almost all countries in the world have reported positive cases of Covid-19, with a global number of cases of more than 3.5 million, with the number of victims almost reaching 500 thousand people. The catastrophic occurrence of pandemic outbreaks that are expected to occur and repeat every century, for cases in Indonesia shows a fairly high number of cases, which is as many as 11,587 people exposed positively, with the death toll as many as 864 people, although the recovered also continue to show an increase to 1,954 people as of May 4, 2020. [3]

As a non-natural disaster in the field of health that indonesia has experienced in the last five decades, the impact caused by this pandemic disaster is multidimensional and spread almost throughout the province, and not only limited to the health sector, where the national disaster status of the health sector has been established, but has a very significant impact on other fields, Especially economic and socio-cultural. The enactment of psbb policy (largescale social restrictions) and the prohibition of homecoming and returning, especially during Ramadan before Eid, has implications for massive economic conditions, which can be compared to the economic crisis that occurred in 1998 ago, and even worse when compared to the economic crisis that occurred in 2008 , in addition to the socio-cultural impact with the restriction or prohibition of homecoming and returning home in the month of 2008. Ramadan and Eid al-Fitr in 2020. [3]

In fact, the Government has been very responsive in issuing variousIregulatory frameworks primarily aimed at reducing the potential spread of the Covidd-19 pandemic outbreak transmitted from human to human, but the fact that increasing the number of cases, fatalities, and geographical distribution of the Covid-19 pandemic shows that efforts are still needed that are not only the responsibility of the Government, But it can involve the participation of all elements of society, or in other words a participatory approach is needed in handling Covid-19, through the involvement of various stakeholders, especially local communities, considering that the source of transmission is human, individually, extending to the community, to the regional and national level and continuing to the regional and global levels.[3]

Given the current evidence that is still very limited regarding 2019-nCoV infection and its transmission pattern, in the $2019-\mathrm{nCoV}$ surveillance is carried out and monitored in the 
hospital. However, for cases in monitoring given home care (self-isolation) while keeping in mind the possibility of worsening. If clinical symptoms experience worsening then immediately check yourself into a health care facility.[3]

GPOverment asked patients without symptoms and mild symptoms to do selfisolation at home, in order to reduce the burden of hospitalization. However, self-isolation does not always go smoothly. Sekain sometimes not handled properly and eventually Covid 19 patients die, some of which even cause newclusters at the family level due to lack of understanding in self-isolation. The Director of Prevention and Control of Infectious Diseases stated that those who are obliged to self-isolate are people who are tested with positive results of Covid 19. The length of self-isolation that patients go through positive Covid 19 without symptoms is 10 days of isolation since the antigen test or PCR postif Covid 19. For close contact patients, the duration of self-isolation is 14 days from contact with Covid 19 cases. After a period of selfisolation, the patient needs control to thehealth bag and is not required to haveanother PCR test.[3]

President Joko Widodo has signed Monday, July 20, 2020, Presidential Regulation No. 82 of 2020 on the Committee on Handling Corona Virus Disease 2019 (Covid-19) and National Economic Recovery The Task Force for Accelerating the Handling of Covid-19 is also abolished by this order. Instead, Jokowi established a Covid-19 Task Force. Doni Monardo, the head of the National Disaster Management Agency (BNPB), is named the task force's coordinator. Article 6 explains, the Covid-19 Handling Task Force is tasked with implementing and controlling the implementation of strategic policies related to the handling of Covid-19. Then, point 2 of the articles mentions, this task force is also tasked with solving strategic policy problems related to handling the virus quickly and appropriately.[2]

In RT (Rukun Tetangga) 07 Bekasi has $150 \mathrm{KK}$ who have tremendous potential in mosque, youth and PKK activities for citizen activities around RT 07 neighborhood. Thisotensi needs to be empowered in the framework Because the corona virus disease 2019 (covid-19) is a new virus pandemic requires all of us to take preventive measures to always be healthy wal afiat (GÜNER et al., 2020). Many recommendations are done by experts who all recommend to keep healthy in the face of an increasingly widespread pandemic. To effectively alert pandemic covid-19 in RT 07 Bekasineed to be formed task force to be more empowered. Once formed, it will then be trained to carry out the main tasks and functions (TUPOKSI) of this task force. One of the duties of the task force is the education of citizens with preventive measures (Nafilah \& Muflihah, 2020; James et al., 2020).

This prepared task force is actually an embodiment of the community's response to policies that have been set by the central government and local governments. According to this Presidential Decree, one of the tasks of the The goal of the Covid-19 Handling Task Force is to increase readiness and capability in the prevention, detection, and response to Covid-19. (Presidential Decree No. 7 of 2020 of the Republic of Indonesia about the Task Force on Accelerating the Treatment of Corona Virus Disease in 2019). On Wednesday (06/16/2021), there were 120,306 active cases of Covid-19 in Indonesia. This equates to $6.2 \%$ of all Covid19 positive cases. From the previous day, the number of active cases rose by 3,519. A patient who has tested positive for Covid-19 and is being treated is considered an active case. The number was calculated by dividing the total number of Covid-19 positive cases by the number of positive cases cure and death rates.[11]

\section{Research Method}


This research aims for the evaluation on behalf of the Covid 19 Task Force (UnitTugas) accuracy of drug administration according to complaints, the duration of the task force response to complaints, compliance of self-isolation patients taking drugs and the duration of recovery in RT 07 RW 25 Bekasi City. This research is a type of exploratory descriptive research so it is not intended to test hypotheses.

The sample selection technique was conducted through accidental sampling with snowball sampling as many as 32 self-isolation patient respondents from 53 isoman patients in RT 7 RW 25 bekasi city as a sample. The method of data collection uses self administrated surveys, by providing questionnaires. Meode analysts in this study are by descriptive analysis methods.

\section{Results and Discussion}

\subsection{Results}

The result of the evaluation of task force performance against the accuracy of drug administration according to complaints were drawn in the Figure 1.

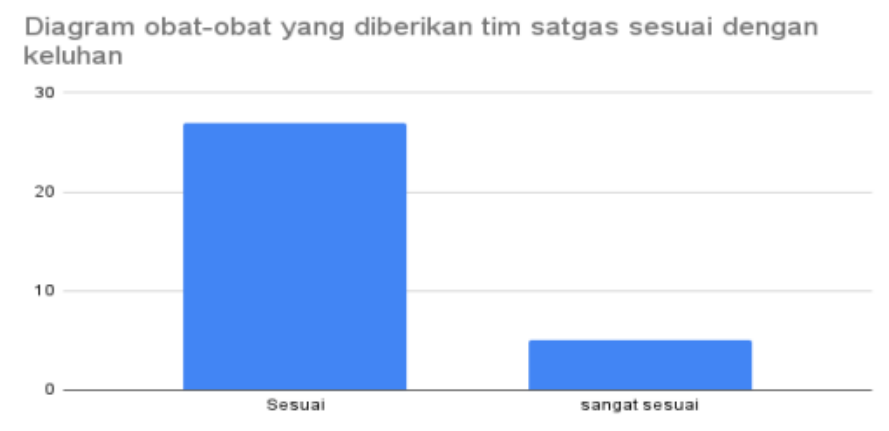

Fig. 1. Evaluation of task force performance against the accuracy of drug administration according to complaints.

The result of the evaluation of the Performance of the Task Force team against the responsiveness of complaints was shown in the Figure 2.

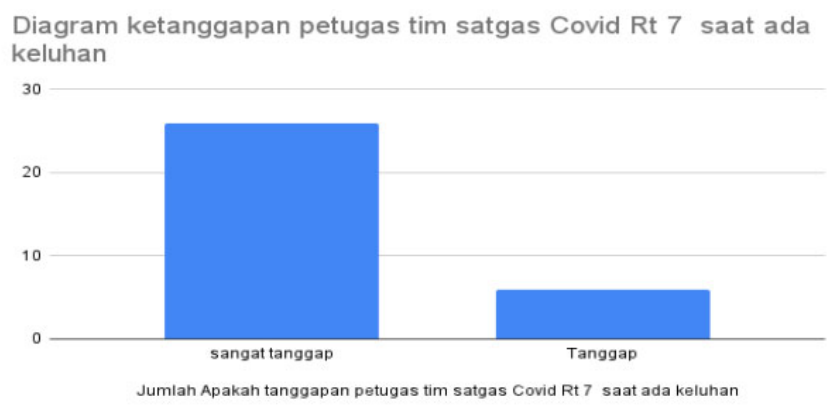

Fig. 2. Evaluation of the Performance of the Task Force team against the responsiveness of complaints 
The findings of the evaluation of task force performance to compliance of self-isolation patients taking drugs were shown in Figure 3.

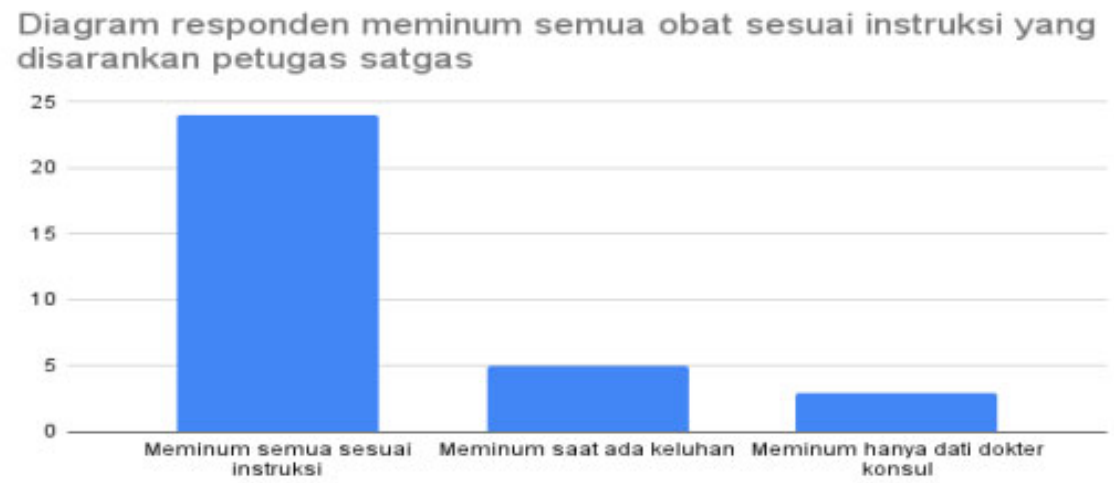

Fig. 3. Evaluation of task force performance to compliance of self-isolation patients taking drugs

Figure 4 showed the results of the evaluation of the performance of task force Covid-19 against the need for task force Covid 19.

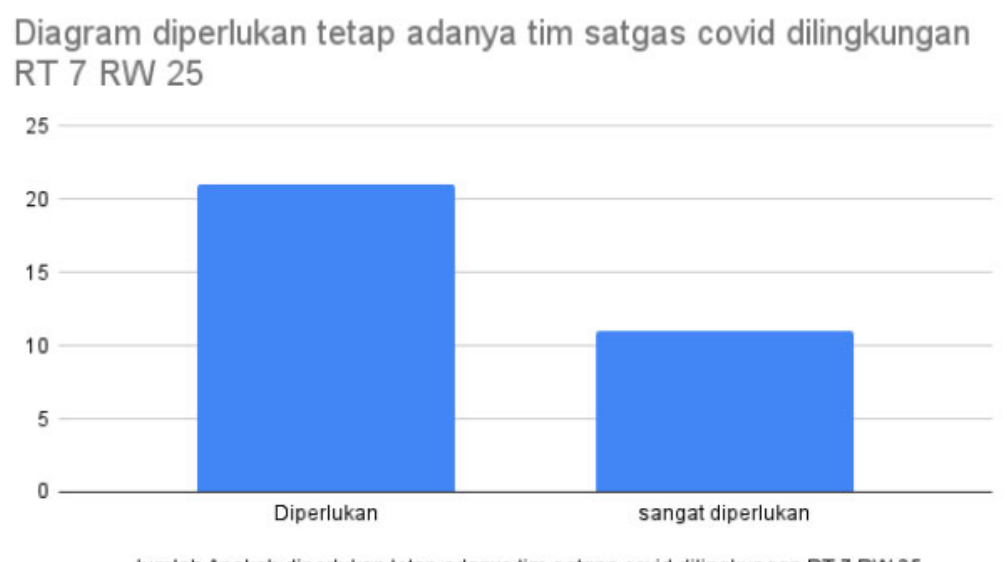

Jumlah Apakah diperlukan tetap adanya tim satgas covid dilingkungan RT 7 RW 25

Fig. 4. Evaluation of the performance of task force Covid-19 against the need for task force Covid 19

The results of the evaluation of Task Force Team On the duration of recovery was depicted in Table 1. 
Table 1. Evaluation of Task Force Team On the duration of recovery

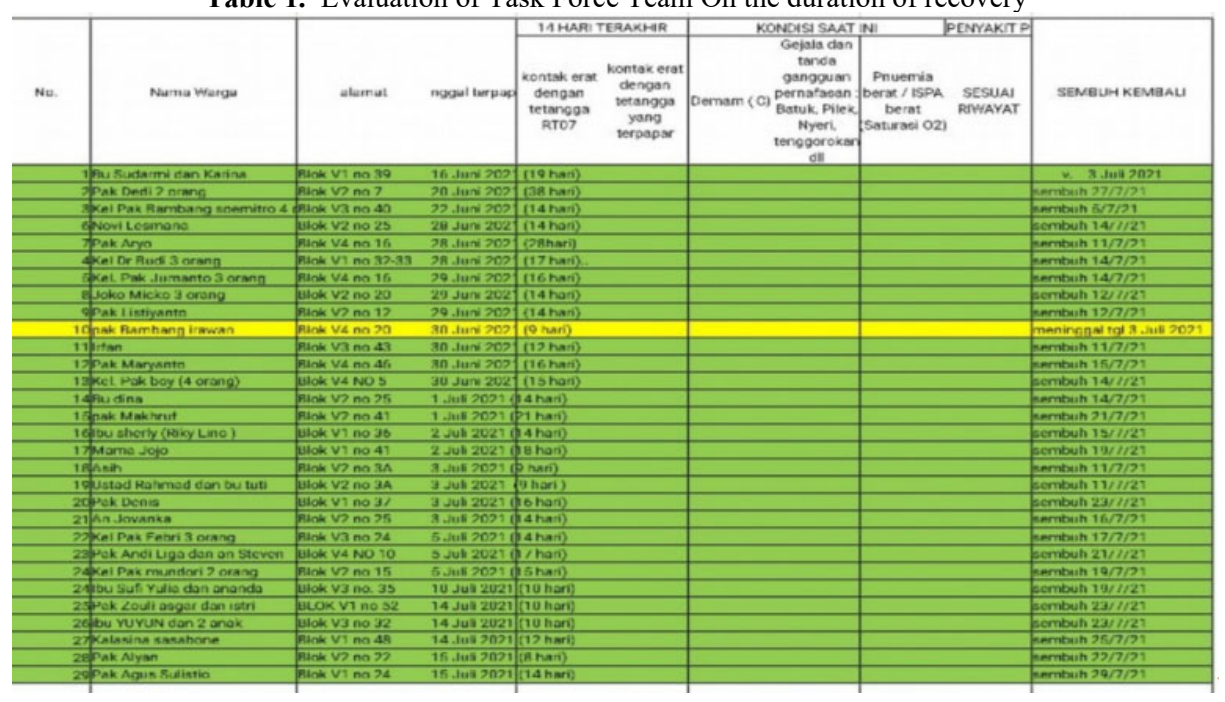

\subsection{Discussion}

This study showed that the TASK FORCE RT 7 RW 25 against the accuracy of drug enforcement as many as 25 people with a percentage of $78.1 \%$ in accordance with complaints and 7 people with a percentage of $21.3 \%$ were very appropriate. For the duration of complaint response is very responsive as many as 25 people with a percentage of $78.1 \%$ and 7 people responding with a percentage of $21.3 \%$. In self-medication compliance patients took the drug varied, namely as many as 25 people with a percentage of $78.1 \%$ taking as instructed, 4 patients with a percentage of $12.5 \%$ took when there was a complaint, and 3 people with a percentage of $8.4 \%$ did not take the drug given by the task force (taking only from a doctor's prescription when first consul. For the long duration of recovery showed the results of 1 person out of 53 patients isoman long duration recovery 8 days, 3 people from 53 people recovery duration 9 days, 7 people from 53 people recovery duration 10 days, 1 person from 53 people recovery duration 11 days. And the rest spent a duration of 14 days to 39 days of recovery duration until the PCR results came back negative.

Result esearched the survey also obtained the advice of respondents that there still needs to be a Covid 19 task force and always run health protocols until the Covid 19 pandemic is declared over by the central government. Hopefully this research is useful for us, especially the author who is currently the Covid 19 Task Force and generally for local and central governments as an evaluation in the future to make the covid-19 task force always trained and leading when there are self-isolation patients in the environment.

\section{References}

[1] Tim torja Ministry of Home Affairs to support the covid-19 group. General guidelines for dealing with the covid19 pandemic for local governments prevention, government, diagnosis and management. Jakarta. (2020). 
[2] Satuan task handling covid-19.

[3] CITATION Sup201 \1 1033

[4] The Building Team of the Directorate General of Prevention and Control of Infectious Diseases. Guidelines for preparedness for novel coronavirus infection 2019.Jakarta. (2020).

[5] Kementerian Kesehatan Circular Letter No. HK. 02.01/Menkes/202/2020 on selfisolation protocols in the handling of coronavirus disease (covid-19). Jakarta. (2020).

[6] Antara/POOL / Sigid Kumiawan. 4 Role of Task Force handling Covid-19 Replacement Task Force. Dakses tamggal August 23. Jakarta. (2021).

[7] Republic of Indonesia. Presidential Regulation No. 82 of 2020 concerning the Committee on Handling Corona Virus Desease 2019 (Covid-19) and National Economic Recovery. (2020).

[8] Güner, R., hasanoğlu, İ., \& aktaş, F. COVID-9: Prevention and control measures in community. Turkish Journal of Medical Sciences, 50(3), 571-577. (2020). https://doi.org/10.3906/sag-2004-146.

[9] Nafilah, Z. A., \& Muflihah. Tactical Measures for Covid-19 Prevention in Lowayu Village of Gresik District Shaman District. Proceedings of Research and Community Service,7(2),360-370. (2020).

[10] https://doi.org/10.24198/jppm.v7i2.28821

[11] https://covid19.who.int/table https://covid19.who.int/table 